\title{
The Space and Place of Humans and Humanity in Language: Arabic and Indonesian Compared
}

\author{
MUASSOMAH*, IRWAN ABDULLAH, M. FAISOL \& HASBOLLAH TOISUTA ${ }^{1}$
}

\begin{abstract}
Language, aside from representing the culture of a people, also constructs humankind and humanity. Arabic conceptualizes humanity differently than the world's other languages, such as Indonesian. In Arabic, humans are positioned as subordinate, as dependent on God, whereas in Indonesian they are characterized as autonomous. This article seeks to analyse how language positions humans within their relationships with God, other humans, and nature. Arabic and Indonesian both incorporate implicit concepts of human being, godliness, and humanity, and thus these languages have broad space for defining humanity's relationship with God. This article concludes that Arabic positions humans as creatures whose values and attitudes are dependent on God, while Indonesian positions humans as autonomous and free creatures. The link between Arabic and religion and between Indonesian and culture has informed how these languages conceptualize and position humanity. This study recommends a comprehensive comparative investigation of how various languages position and understand humans and humanity.
\end{abstract}

Keywords: Arabic language, humanity, Indonesian language, relationships with God, space and place

Language, with its ability to construct reality, also has the special ability to position humans and humanity. Arabic conceptualizes humans and humanity differently than other languages, such as Indonesian. This is evident in its subject structure; Arabic positions humans as passive subjects whose every situation is determined by God's power (Leaman 2012), while Indonesian positions humans as active subjects with the authority and independence to define themselves and their social presence. For instance, the Indonesian-language sentences Saya naik mobil (I go by car) and Ali meninggal (Ali died) translate to "I am taken by car" and "Ali is made dead" in Arabic. Language is thus used to show God's power over humanity and Creation (Egginton \& Egginton 2015), even as the debate between fatalism and free will, between humans as creation and humans as creators, continues (Bayer 2004).

Studies of language have tended to take three perspectives. First, language has been viewed as a means of communication, as a means of connecting humans with other humans or with the outside world (Rickheit \& Strohner 2008; Tager-Flusberg, Paul \& Lord 2013; Richards and Schmidt, 2014). As stated by Rickheit and Strohner, linguistic competence is an important

\footnotetext{
1 Muassomah* (corresponding author), Ph.D, lecturer at the Department of Arabic Language and Literature, Faculty of Humanities, Maulana Malik Ibrahim State Islamic University, MALANG, Indonesia, email: muassomah@bsa.uin-malang.ac.id; Irwan Abdullah, Ph.D., Professor of Anthropology at the Department of Anthropology, Faculty of Cultural Sciences, Gadjah Mada University, YOGYAKARTA, Indonesia, email: irwan-fib@ugm.ac.id; M. Faisol, Ph.D., senior lecturer at the Department of Arabic Language and Literature, Faculty of Humanities, Maulana Malik Ibrahim State Islamic University, MALANG, Indonesia, email: mfaisol@bsa.uin-malang.ac.id; Hasbollah Toisuta, Ph.D., senior lecturer in Islamic Studies at Graduate Program, State Institute of Islamic Studies, AMBON, Indonesia, email: hasbollah.toisuta@iainambon.ac.id.
} 
part of the communication process, both verbal and non-verbal. At the same time, language determines order and disorder in the communication process (Rickheit \& Strohner 2008). Second, language has been perceived as an important factor in creating individual and collective identity (Bucholtz \& Hall 2007; Willis 2010; Darvin \& Norton 2015; Norton 2018), as well as establishing power structures (Wodak 2012). Third, studies have investigated the language learning process, as well as various methods used to overcome learning difficulties (Ellis 2012; Hall \& Cook 2012; Alqahtani 2015; Liep \& Špona, 2015; Moeller \& Catalano 2015; Hinkel 2016). None of these approaches consider the link between language and religion or recognizes that language incorporates spiritual statements that necessitate careful investigation.

This article is intended to fill this gap by providing a detailed analysis of the relationship between language and religion through comparison of Arabic and Indonesian. As such, it seeks to answer three research questions: (a) How do Arabic and Indonesian conceptualize humans and humanity?; (b) How do different conceptualizations of humanity (as dependent and independent) occur in Arabic and Indonesian?; and (c) How do the different conceptualizations of humanity in Arabic and Indonesia influence speakers' understanding of the relationship between humanity and God? These three questions offer a means of understanding the process through which humans are conceptualized and structured through language. All languages embody specific ideologies that inform how they position humanity.

This article departs from the assumption that Arabic and Indonesian conceptualize humanity differently. Arabic positions humans as creatures without autonomy, who depend solely on God, while Indonesian conceives humans as perfect beings with the authority and freedom to determine their own fates. In Arabic, humans are defined by God's power, with their continued survival depending on God's will. As such, Arabic is a sacred language, while Indonesian is a profane language.

\section{Linguistic Construction of Humanity}

Language is often taken for granted, even though it constructs various aspects of human life, preserving social stratifications and creating cultural identities (Khokhar, Memon \& Siddique 2016). Studies have often perceived language as an object, as something created by humanity, rather than as a subject capable of constructing humanity. Citing Levinas, Werhane (1996) writes that we cannot be defined except through the communities with which we interact. In other words, we are born and find ourselves in a world that has already been shaped by language. Community itself is a social construct, created through language; national, ethnic, religious, and tribal identity are linguistic constructs. As such, Lehnert (1997) argues that language can also free individuals from the restraints of their community identities.

A study conducted by Khokhar, Memon \& Siddique (2016) focusing on individuals who abandon their indigenous language for a stronger language in Pakistan, finds that language plays a significant role in shaping individual identity and in distinguishing different groups. According to MacWhinney (2005), language offers a means of constructing love and friendship, a basis for male-female relationships, and a way to detect continued infidelity. Grammar thus makes complex social relationships. Elsewhere, Young (2016) described pre-colonial Africa as "a continent without language", wherein complicated communication did not occur. Language, as well as its sociocultural implications, were introduced through Western colonialism and complicated life in Africa.

The relationship between God and humanity has been hotly debated in academia. According to Cailing (2018), God-human relations originated from a fear of the Almighty. As such, 'fear' is the foundation for a hierarchy that positions God as the creator of heaven and earth and humans as His 'servants' (Haight 2018; Mercier, Kramer \& Shariff, 2018). As humans were created by God, their very existence is defined by Him, and as such their belief system and ethical codes emphasize serving Him (Cailing 2018). According to Irving (2018), because humans were created 
by God, they have certain divine characteristics. Although these divine characteristics are derived from Him, they do not change humans' fundamental humanity. Humans' cognitive powers are derived from God's revelations, as passed through sacred texts (Irving 2018).

Synthesizing rational structures and intuitional materials, Torrance reverses how cognitive mechanisms functions: material content and knowledge does not derive deterministically from human cognitive structures, but human cognitive structures are derived from their material content and knowledge (Irving 2018). Humans understand not only the knowledge they receive, but also the process through which they and the world were created (Kelly 2015). Studies of the relationship between God and humanity can be divided into two categories: (1) God-human relations as the source of human rationality (Kelly 2015; Haight 2018; Irving 2018; Laurin, Schumann \& Holmes 2018; Mercier, Kramer \& Shariff 2018); and (2) Godhuman relations as the source of human morality (Gray \& Wegner 2010; Meadowcroft 2015; Whitt 2016; Heller 2017; Murphy 2018; Wu \& Cutright 2018). Both morally and rationally every individual as a human who is inseparable from the creator has responsibility for all of his actions (Nooraini \& Salasiah 2013).

\section{Differences between Arabic and Indonesian}

To distinguish between the sacred and profane, it is necessary to begin with an understanding of religion and language. Rennie (2007), for example, borrows from William James and defines religion as "the apprehension of some 'order', specifically some order to which we can 'harmoniously adjust' our behaviour to our own ultimate benefit, and this may be seen as selfevidently adaptive". Language is thus a means of communicating experiences that facilitate or promote such a perception of order. According to Eliade (1959), sacred language departs from humanity's inability to express ganz andere-all that goes beyond man's natural experience. Anderson (1991) argues that, through sacred language, communities can establish relationships with super-terrestrial structures.

Conversely, according to Kuo (2015), the profane world is a social construct in which communities share a homogenous understanding of order. As such, the profane refers to hierarchies, structures, languages, and institutions. Karelin as cited by Bennett (2018), likens profane language-identified as 'vernacular language' - to water: functional and transparent. Sacred language, meanwhile, is like wine: less practical, but it gladdens the heart. Neither type of language is appropriate for every situation. Water and wine both have their place and their time. Sancta sancte-"sacred things require sacred treatments" (Bennett 2018).

Eliade (1959) takes an example from an indigenous American language, which uses the same term for world and year. When the Yokuts say "the world has passed", they mean "a year has passed". Eliade argues that the cosmos is understood as a living being, as something that is born, grows, and dies over the course of the year. As such, there is a close spiritual link between space and time, both of which are divine. As another example, Eliade (1959) notes that several European terms for 'children' (Kinderbrunnen, Kinderteiche, Bubenquellen, etc.) all imply a place, an emotional link that reaches beyond simple family and ancestral bonds. Tankard (1975) argues that sacred language becomes profane when it is used to 'sell' something: advertising "can only be to cheapen the word and to increase distrust between people, because the most sacred words we have are being used to get something from us. Moore (2013) identifies Arabic as the most sacred language, as knowledge and religious practices are inexorably linked within it. As Hindus must know certain Sanskrit terms, Muslims must have a knowledge of Arabic to participate productively in their religious community.

Several academics have used contrastive analysis to distinguish between Arabic and Indonesian (Nur 2016; Hidayah 2013). Contrastive analysis focuses on the differences between two or more languages, enabling researchers to identify the unique characteristics of each 
language as well as the cultural differences that inform its use (Nur 2016). To exemplify these cultural differences, Nur (2016) shows that agrarian Indonesia has numerous terms that refer to its staple food: padi (unharvested rice), gabah (unhusked rice), beras (husked rice), and nasi (cooked rice). Arabic, meanwhile, only has one word for rice: ruzz. Conversely, Arabic has multiple terms to refer to camels (jamal, 'ibil, ba'îr, dhāmir, nāqah, 'isyār, and mi'syār), while Indonesian only has one (unta).

These languages also differ in their treatment of gender. Arabic has a strict masculinefeminine dichotomy. Almost all Arabic words, including verbs, are classified as masculine or feminine. Indonesian, conversely, has very few gendered words, and all of these are nouns (Nur, 2016). Arabic and Indonesian also differ in their conjugation of verbs; Arabic requires verbs to be conjugated in accordance with tense, amount, gender, and grammatical person, while Indonesian does not (Nur 2016). Academics have investigated these languages' different grammatical patterns, affixation tendencies (Hidayah 2013), pronoun systems (Markhamah et. al. 2017) and use of reciprocal verbs (Budiono 2016). Scholars have also examined the extent to which phonetics, grammar, script, morphology, and semantics influence language learning (Hidayat 2012) and translation (Al-Farisi 2015).

\section{The Research Method}

This article examines how Arabic and Indonesian conceptualize humans and humanity, arguing that their conceptualizations are nearly oppositional. Arabic positions humans as powerless and as relying on a higher power, whereas Indonesian conceives them as autonomous and selfdeterminant. In other words, Arabic views humans as dependent and Indonesian views them as independent. In examining this phenomenon, this article employs a bibliographic approach, collecting its data from documents (books and articles). Contrastive analysis is used to understand how humans and humanity are conceptualized in Arabic and in Indonesian.

Data were collected through several stages. Initially, Arabic and Indonesian-language sentences dealing with human activities were observed and contemplated. These sentences were then rewritten and presented in table format, with a focus on their definitions of humanity. Subsequently, these data were divided into two categories: conceptualizations of humanity in Arabic and conceptualizations of humanity in Indonesian.

Data were analysed using the technique proposed by Milles and Hubbermans: collection, presentation, reduction, and verification. Data regarding the conceptualization of humanity in Arabic and Indonesian, as well as data regarding sentence structure, were presented. Data were then reduced (discarding data that did not support the research) and verified. Finally, these data were displayed in several tables. Data regarding the linguistic conceptualization of humans and humanity in Arabic and Indonesian were analysed using a contrastive approach, while data regarding sentence structure were analysed by identifying textual and contextual meaning.

The positioning of humans and humanity in Arabic and Indonesian implies different assumptions. Three aspects of these languages' positioning of humanity are discussed: conceptualizations of humanity, characteristics attributed to humans as part of their existence, and the implications of these conceptualizations and characteristics for humanity's relationship with God.

\section{Conceptualizations of Humanity in Arabic and Indonesian}

The different conceptualization of humanity inherent in Arabic and Indonesian is evident in these languages' positioning of humans relative to other beings. Humans are identified as having specific characteristics, and following certain moral guidelines, as seen in Table 1. 
Vol. 18: (Dec.) 2020

Table 1. Different Conceptualizations of Humanity in Arabic and Indonesian

\begin{tabular}{|c|c|c|c|c|}
\hline \multirow[t]{2}{*}{ No. } & \multicolumn{4}{|c|}{ Conceptualizations of Humanity } \\
\hline & Arabic & Indonesian & English & Interpretation \\
\hline 1. & الإنسان حيو ان ناطق &  & $\begin{array}{l}\text { Man is an animal } \\
\text { with a mind. }\end{array}$ & $\begin{array}{l}\text { Humans are being with a rational } \\
\text { mind (capable of controlling other } \\
\text { beings). }\end{array}$ \\
\hline 2 & 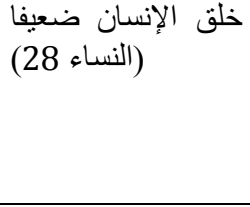 & $\begin{array}{l}\text { Manusia } \\
\text { diciptakan } \\
\text { sebagai makhluk } \\
\text { yang lemah }\end{array}$ & $\begin{array}{l}\text { Man was created } \\
\text { weak. }\end{array}$ & $\begin{array}{l}\text { Humans are social beings, meaning } \\
\text { that they live together with other } \\
\text { humans and cannot do their } \\
\text { everyday activities without } \\
\text { involving others. }\end{array}$ \\
\hline 3. & صلقد خلقنا الإنسان من حمب & $\begin{array}{l}\text { Dan } \\
\text { sesungguhnya } \\
\text { Kami telah } \\
\text { menciptakan } \\
\text { manusia (Adam) } \\
\text { dari tanah liat } \\
\text { kering (yang } \\
\text { berasal) dari } \\
\text { lumpur hitam } \\
\text { yang diberi } \\
\text { bentuk }\end{array}$ & $\begin{array}{l}\text { And We did } \\
\text { certainly create } \\
\text { man out of clay } \\
\text { from an altered } \\
\text { black mud. }\end{array}$ & $\begin{array}{l}\text { Humans are capable of } \\
\text { contemplation. }\end{array}$ \\
\hline 4. & خلق الإنسان من نطفة & $\begin{array}{l}\text { Manusia } \\
\text { diciptakan dari } \\
\text { air mani }\end{array}$ & $\begin{array}{l}\text { He has created } \\
\text { man from a sperm- } \\
\text { drop. }\end{array}$ & $\begin{array}{l}\text { Unlike animals, humans do not have } \\
\text { a limited world around them (Max } \\
\text { Scheler, 1974) }\end{array}$ \\
\hline 5. & كفورا (الإسر اء 67 الإنسان) & $\begin{array}{l}\text { Dan manusia itu } \\
\text { adalah } r \text { selalu } \\
\text { tidak berterima } \\
\text { kasih }\end{array}$ & $\begin{array}{l}\text { And ever is man } \\
\text { ungrateful. }\end{array}$ & $\begin{array}{l}\text { Humans are "who and what" and } \\
\text { "what and who", being } \\
\text { material/physical and spiritual }\end{array}$ \\
\hline 6. & 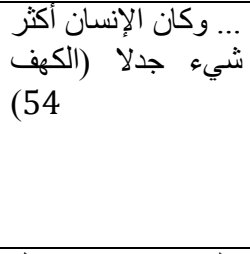 & $\begin{array}{lr}\text { Dan manusia } \\
\text { adalah } & \text { makhluk } \\
\text { yang } & \text { paling } \\
\text { banyak } & \\
\text { membantah. }\end{array}$ & $\begin{array}{l}\text { And mankind has } \\
\text { ever been, most of } \\
\text { anything, prone to } \\
\text { dispute. }\end{array}$ & $\begin{array}{l}\text { Humans are monopluralistic } \\
\text { beings, meaning that they consist of } \\
\text { body and soul, individual and social, } \\
\text { and exist both as autonomous } \\
\text { beings and as God's creations } \\
\text { (Notonegoro 1987). }\end{array}$ \\
\hline 7. & خلق الإنسان من عجل & $\begin{array}{l}\text { Manusia telah } \\
\text { dijadikan } \\
\text { (bertabiat) } \\
\text { tergesa-gesa }\end{array}$ & $\begin{array}{l}\text { Man was created of } \\
\text { haste. }\end{array}$ & $\begin{array}{l}\text { Humans are meaningful as } \\
\text { nominals, as nouns, and thus may } \\
\text { have names, places, or all types of } \\
\text { objects and objectifications. }\end{array}$ \\
\hline 8. & إن الإنسان لكفور & $\begin{array}{l}\text { sesungguhnya } \\
\text { manusia itu, } \\
\text { benar-benar } \\
\text { sangat } \\
\text { mengingkari } \\
\text { nikmat. }\end{array}$ & $\begin{array}{l}\text { Indeed, mankind is } \\
\text { ungrateful. }\end{array}$ & $\begin{array}{l}\text { Humans are open beings, free to } \\
\text { identify meaning in any situation, to } \\
\text { make any decision, to survive, and } \\
\text { to create multidimensional } \\
\text { relationships with numerous } \\
\text { possibilities. }\end{array}$ \\
\hline 9. & إن الإنسان لفي خسر 2 العصر) & $\begin{array}{l}\text { Sesungguhnya } \\
\text { manusia itu } \\
\text { benar-benar } \\
\text { dalam kerugian, }\end{array}$ & $\begin{array}{l}\text { Indeed, mankind is } \\
\text { in loss, }\end{array}$ & $\begin{array}{l}\text { According to Omar Mohammad Al- } \\
\text { Toumi Al-Syaibany, humans are } \\
\text { noble beings. Humans are beings } \\
\text { that can think, and consist of three } \\
\text { dimensions (body, soul, and mind). } \\
\text { As they develop, humans are } \\
\text { influenced by two main factors: } \\
\text { heritage and environment. }\end{array}$ \\
\hline
\end{tabular}




\begin{tabular}{|c|c|c|c|c|}
\hline 10. & 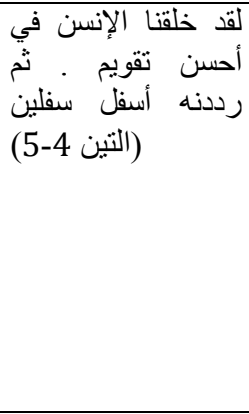 & $\begin{array}{l}\text { Sungguh kami } \\
\text { ciptakan manusia } \\
\text { dengan sabaik- } \\
\text { baik bentuk. } \\
\text { Kemudian Kami } \\
\text { kembalikan dia } \\
\text { ke tempat yang } \\
\text { serendah- } \\
\text { rendahnya } \\
\text { (neraka), }\end{array}$ & $\begin{array}{l}\text { We have certainly } \\
\text { created man in the } \\
\text { best of stature; } \\
\text { Then We return } \\
\text { him to the lowest } \\
\text { of the low, }\end{array}$ & $\begin{array}{l}\text { According to Kees Bertens, humans } \\
\text { are beings that consist of two } \\
\text { elements, neither of which can be } \\
\text { identified individually. }\end{array}$ \\
\hline 11. & 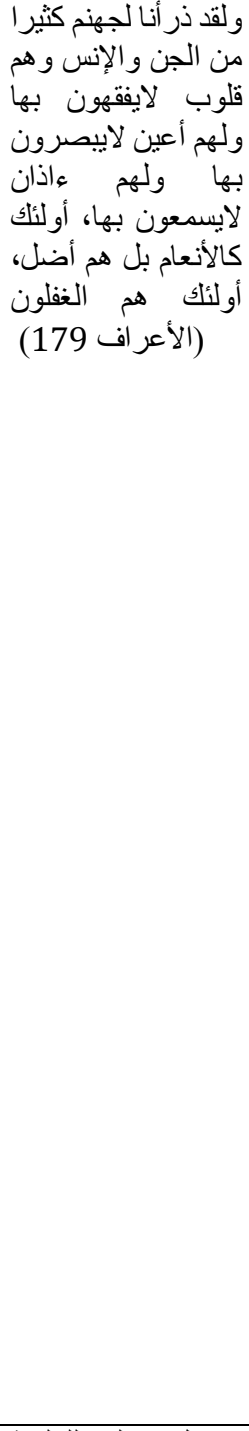 & $\begin{array}{l}\text { Dan } \\
\text { sesungguhnya } \\
\text { Kami jadikan } \\
\text { untuk (isi neraka } \\
\text { Jahannam) } \\
\text { kebanyakan dari } \\
\text { jin dan manusia, } \\
\text { mereka tidak } \\
\text { mempunyai hati, } \\
\text { tetapi tidak } \\
\text { dipergunakannya } \\
\text { untuk memahami } \\
\text { (ayat-ayat Allah) } \\
\text { dan mereka } \\
\text { mempunyai mata } \\
\text { (tetapi) itu } \\
\text { dipergunakannya } \\
\text { untuk melihat } \\
\text { (tanda-tanda } \\
\text { kekuasaan Allah), } \\
\text { dan mereka } \\
\text { mempunyai } \\
\text { telinga (tetapi) } \\
\text { tidak dipergunakannya } \\
\text { untuk mendengar } \\
\text { (ayat-ayat Allah). } \\
\text { Mereka sebagai binatang } \\
\text { ternak, bahkan } \\
\text { mereka lebih } \\
\text { sesat lagi. Mereka } \\
\text { itulah orang- } \\
\text { orang yang lalai. }\end{array}$ & $\begin{array}{l}\text { And We have } \\
\text { certainly created } \\
\text { for Hell many of } \\
\text { the jinn and } \\
\text { mankind. They } \\
\text { have hearts with } \\
\text { which they do not } \\
\text { understand, they } \\
\text { have eyes with } \\
\text { which they do not } \\
\text { see, and they have } \\
\text { ears with which } \\
\text { they do not hear. } \\
\text { Those are like } \\
\text { livestock; rather, } \\
\text { they are more } \\
\text { astray. It is they } \\
\text { who are the } \\
\text { heedless. }\end{array}$ & $\begin{array}{l}\text { According to D. Nicolaus and \& A. } \\
\text { Sudiarja, humans are } \\
\text { simultaneously plural and singular. } \\
\text { Humans are plural because they } \\
\text { have bodies and souls, but also } \\
\text { singular because individual humans } \\
\text { have only one body. }\end{array}$ \\
\hline 12. & خإني جاعل في الأرضئة للمئكة & $\begin{array}{l}\text { Ingatlah ketika } \\
\text { Tuhanmu } \\
\text { berfirman } \\
\text { kepada para } \\
\text { Malaikat: } \\
\text { "Sesungguhnya } \\
\text { Aku hendak } \\
\text { menjadikan } \\
\text { seorang khalifah } \\
\text { di muka bumi" }\end{array}$ & $\begin{array}{l}\text { And [mention], } \\
\text { when your Lord } \\
\text { said to the angels, } \\
\text { "Indeed, I will } \\
\text { make upon the } \\
\text { earth a successive } \\
\text { authority." }\end{array}$ & $\begin{array}{l}\text { According to Erbe Sentanu, humans } \\
\text { are the greatest of God's creations. } \\
\text { Indeed, humans may be identified } \\
\text { as more perfect than any of God's } \\
\text { other creations. }\end{array}$ \\
\hline
\end{tabular}




\begin{tabular}{|c|c|c|c|c|}
\hline 14. & $\begin{array}{l}\text { وكان الإنسان قتتوراء 100) } \\
\text { 100 }\end{array}$ & $\begin{array}{l}\text { Sesungguhnya } \\
\text { Manusia itu } \\
\text { sangat kikir }\end{array}$ & $\begin{array}{l}\text { And ever has man } \\
\text { been stingy. }\end{array}$ & $\begin{array}{l}\text { According to Socrates, humans are } \\
\text { furless and clawless beings with } \\
\text { two legs. }\end{array}$ \\
\hline 15. & إن الإنسان إبران لظلوم & $\begin{array}{l}\text { Sesungguhnya } \\
\text { manuisa itu } \\
\text { sangat dzalim } \\
\text { dan mengingkari } \\
\text { ni'mat Allah }\end{array}$ & $\begin{array}{l}\text { Indeed, mankind is } \\
\text { [generally] most } \\
\text { unjust } \quad \text { and } \\
\text { ungrateful. }\end{array}$ & $\begin{array}{l}\text { According to J. I. Abineno, humans } \\
\text { are 'bodies that are complemented } \\
\text { with souls' rather than 'eternal } \\
\text { souls that exist or are constituted } \\
\text { within a physical body'. }\end{array}$ \\
\hline 16. & إنل الإنسان المعارج 19) & $\begin{array}{l}\text { Sesunggunya } \\
\text { manusia } \\
\text { diciptakan } \\
\text { bersifat keluh } \\
\text { kesah lagi kikir. } \\
\end{array}$ & $\begin{array}{l}\text { Indeed, } \begin{array}{r}\text { mankind } \\
\text { was } \\
\text { anxious: }\end{array} \\
\end{array}$ & $\begin{array}{l}\text { According to I Wayan Warta, } \\
\text { humans are dynamic beings that } \\
\text { consist of body, mind, and soul } \\
\text { (cipta, karsa, and rasa) }\end{array}$ \\
\hline 17. & $\begin{array}{l}\text { إن الإنسان لرباد لكنود (العاديات } \\
\text { (العنات }\end{array}$ & \begin{tabular}{l}
\multicolumn{2}{l}{ Sesungguhnya } \\
manusia itu \\
sangatt ingkar \\
tidak \\
berterimakasi \\
kepada \\
Tuhannya
\end{tabular} & $\begin{array}{l}\text { Indeed mankind, } \\
\text { to his Lord, is } \\
\text { ungrateful. }\end{array}$ & $\begin{array}{l}\text { According to Agung P. P., humans } \\
\text { are the most perfect of God's } \\
\text { creations, consisting of a body, soul, } \\
\text { and mind, and growing within a } \\
\text { specific environment. }\end{array}$ \\
\hline
\end{tabular}

Table 1 shows three tendencies in conceptualizing humanity. First, in Arabic humanity is positioned as relying on a higher power; as such, humans are neither independent nor autonomous. Conversely, Indonesian tends to emphasize human authority and free will. Second, in Arabic humanity is conceived as eternally related to and interacting with other beings, and thus defined through these relationships. In Indonesian, humans are relatively self-contained; in other words, they exist separately from animals and djinns. Third, Arabic positions humans as being dynamically conditioned to seek betterment. Meanwhile, Indonesian views humans as relatively static and fixed. In other words, Arabic perceives humanity as constantly striving for perfection, while Indonesian understands humanity as having (almost) achieved perfection.

\section{Human Dependence and Independence in Language}

Humans and humanity are characterized through their representation and through the events that define their existence. As seen in Table 2, Arabic and Indonesian are nearly opposed in their representation of humanity. This implies a different ideological framing of human existence.

Table 2. Arabic-language Representations of Humanity

\begin{tabular}{|c|c|c|c|}
\hline No. & Ta'bir (in Arabic) & Lexical Meaning & Contextual Meaning \\
\hline 1 & ذهبتُُ إلى الجامعة بالسيارة & I go to campus carried by a car. & I go to campus by car. \\
\hline 2 & أصـابني المرض & Illness has befallen me. & I am sick. \\
\hline 3 & غلبني النوم & Sleep has defeated me. & I am asleep. \\
\hline 4 & غلبني الجوع & Hunger has come upon me. & I am hungry. \\
\hline 5 & تُوُُفي عمر & Umar has been lost. & Umar died. \\
\hline 6 & تركتي الطائرة & The train has left me. & I missed my train. \\
\hline 7 & تركني القطار & The plane has abandoned me. & I missed my plane. \\
\hline 8 & أصسابني الفقر & Poverty has befallen me. & I am poor. \\
\hline 9 & بحزنني سو ءك & Your evils sadden me. & I am sad. \\
\hline 10 & أصـابني المطر & Rain has come upon me. & I am caught in the rain. \\
\hline
\end{tabular}

Through its grammar, Arabic implies the powerlessness of humanity as creations of God (Table 2). All that occurs is outside of human control. In the first example, the Arabic-language 
sentence ذهبثُ إلى الجامعة بالسيارة (I go to campus carried by a car) uses an intransitive verb (fi'il lazim). By implication, one can only reach campus by car with the blessings of God. In the second example, the Arabic-language sentence أصابني المرض (Illness has befallen me) implies that nobody can avoid becoming sick. The third example, غلبني النوم (Sleep has defeated me), implies that one will ultimately fall asleep even as one seeks to stave it away; sleep is inevitable. The fourth example, غلبني الجوع (Hunger has come upon me) indicates an inability to fulfill one's nutritional needs. In the fifth example, a death is referenced with the sentence تُؤفئ عمر; one does not die but is made dead. The actor is ellipsed in this sentence, as it is implicitly understood that death is controlled only by God. The sixth and seventh examples refer to an individual missing a train and plane (تركتي الطائرة) and تركني القطار). The eighth example (أصابني الفقر) implies the inevitability of poverty, while the ninth and tenth examples (يحزنني سوءك) and أصابني المطر) have the same implications for sadness and rain.

In Indonesian, humanity is conceptualized quite differently. Humans are not perceived as subordinate, but rather as independent and powerful. The sentence Saya naik mobil (I go by car) implies a position of authority. Similarly, in Indonesian illness is referenced as neutral, as not deriving from a specific actor; this differs significantly from Arabic, in which the sentence أصابني implicitly positions humanity as powerless. Similarly, the sentence Saya tidur (I sleep) does not necessitate a third party, thereby implying independence. It may thus be surmised that Indonesian does not incorporate cosmological relationships or godliness in its linguistic constructions. The autonomy can lead to a crisis of humanity which is independent of the binding religious structure (Zul'azmi \& Zailan 2012).

\section{Conceptualization of Human-God Relations in Arabic and Indonesian}

Arabic and Indonesian are quite different in their positioning of humans and humanity vis a vis God. Arabic perceives humans as inexorably linked to God, and as such their behaviour is driven by God the Creator. Power flows from God, the Almighty, to humanity, the object of His power. Arabic thus consistently invokes the spiritual link between God and humanity. All Arabic words and sentences imply this relationship.

Conversely, Indonesian perceives humans and humanity as independent of God, as active actors with their own power. It does not imply values of Godliness in its sentences and words. As such, not only does it offer space for other (potentially threatening) ideologies, but it fails to provide a moral foundation for human behaviour. Indonesian is more pragmatic in its approach to communication, prioritizing openness and human interactions. As such, speakers of Indonesian require a source of cultural and religious values that can inform their communication processes.

Arabic consistently implies the presence of God, and godliness informs every human speech, thought, and action. It is thus strongly informed by religious values in its positioning of humanity within the broader cosmos. Indonesian, meanwhile, is more practical and worldly in its approach, being relatively free of ideological values. In other words, Arabic views humans as sharing a sacred bond with a greater power, while Indonesian perceives humans as having their own authority and values. These languages thus have different approaches to spirituality and to understanding humanity's place in the cosmos. Further discussion will focus on the historical contexts in which these languages developed as well as the sociological elements that shaped them.

\section{Humanity: Between Authoritative and Subordinative}

As shown above, Arabic and Indonesian have a different and nearly oppositional conceptualizations of humans and humanity. In Arabic, humans are viewed as passive and weak beings that depend on a higher power. Humanity strives for perfection, which it can obtain only 
through its interactions with God, which can only be manifested through worship. As stated by Cailing, if humans are defined as God's creations, their continued existence is entirely within His hands (Cailing 2018). Conversely, Indonesian conceives humans as able to make their own fates, as having the power to address their own problems, as enjoying broad authority and freedom. This is emphasized by Nasution (2011), who writes that empiric advances in science and technology have facilitated human life and created new paradigms. Humans are thus rationalistic and secular beings, rather than religious ones.

This difference may be attributed to the direct involvement of Arabic in the Islamization process. All of Islam's doctrines and teachings are contained in Arabic-language texts, and as such Arabic has a special standing in the Muslim world (including in Indonesia, where it is closely identified with religion). At the same time, God is always implicitly present in Arabic-language conversations; consequently, God has an undeniable influence on human creative processes (Egginton \& Egginton 2015). Conversely, Indonesian is an egalitarian language, one that has not been directly involved in the propagation of religion. This has influenced the language's conceptualization and perception of humans as autonomous and independent beings. As argued by Nur (2016), the unique characteristics of Arabic and Indonesian are derived from the cultural assumptions that underpin them.

Arabic and Indonesian use different perspectives to conceptualize and position humans and humanity. In Arabic, humans are positioned as inherently interested in advancing moral goals. Having been created by God, humans must seek to follow His moral teachings. Morality is the only measure of human perfection, and all religions view morality as the ultimate goal of human existence and service to God. Indonesian, meanwhile, positions humans as determining their own fates and as possessing autonomy. As argued by Kelly (2015), language provides humans with an understanding not only of their world but also the process through which they were created.

Being created solely to worship God, humans lack self-determination and thus their every behaviour is influenced by other creatures and by a higher power. As stated by Cailing (2018), fear is foundational in humanity's relationship with God, as it is because of fear that humans identify themselves as the 'servants' of God and as beings created by Him (Haight 2018). Arabic thus positions humans as undergoing an exact logical journey, wherein true happiness can only be achieved through interactions with God.

The different conceptualizations of humans and humanity in Arabic and Indonesian have implications for their speakers' level of religiosity. Arabic implies an eternal link between humanity and God; humans are seen as not only interacting with other humans and with their environments, but also as existing through God's will. Conversely, Indonesian does not invoke such a link, instead positioning humans as having the authority and autonomy to shape their own fates. Arabic conceptualizes perfection as requiring hard word and God's blessings, reflecting the argument that language serves not only to facilitate communication between individuals but also between individuals and God (Eliade 1959). Meanwhile, Indonesian structures humans as capable of achieving perfection on their own.

Through its linguistic structures, Arabic implies the presence of God in its every sentence, while Indonesian is more practical and worldly. Religious values are deeply ensconced in Arabic, while Indonesian is relatively free of such ideological content. Arabic and Indonesian thus differ significantly, as shown in comparisons of translation process (Al-Farisi 2015), linguistic structures (Hidayat 2012), pronouns (Markhamah et al. 2017), and reciprocal verbs (Budiono 2016).

This shows language's ability to structure humans and their interactions with God and their environment. Humans' social reality is informed by their interactions with other humans, with other creatures, and with nature, all of which are derived from God's power. Language is thus an important means of constructing reality. 
To conclude, this study has shown that the differences between Arabic and Indonesian influence their speakers' religiosity. Arabic is a sacred language, one that positions humans as inexorably linked to God, while Indonesian is a profane language that views humans as autonomous. Arabic positions humans as seeking perfection through their interactions with each other, with their environment, and with God. Conversely, Indonesian understands humans as authoritative beings that are able to determine their own fates. Each language, shaped by the society in which it developed, structures humanity differently. Arabic tends to emphasize religious values, while Indonesian emphasizes cultural values.

This examination of how humans are conceptualized and classified has shown that different languages frame God-human relations. This study's contrastive approach has enabled it to understand how Arabic and Indonesian conceive humanity's relationship with God, with other creatures, and with their environment. This textual and contextual analysis has shown that Arabic emphasizes values of godliness and humanity, while Indonesian is generally less ideological. Arabic frames humanity as dynamic, as always seeking to improve itself through morality, while Indonesian positions humans as static, nearly perfect, beings.

This analysis of the linguistic structure of Arabic and Indonesian has shown that the former emphasizes divinity while the latter minimizes it. Religious principles are foundational in Arabic, while in Indonesian cultural principles are foundational. This contrastive analysis has promoted an understanding of how humans are linguistically positioned vis a vis God. There are, however, two points that require further consideration. First, this study has not examined the empirical significance of these languages, particularly how their speakers respond to their positioning of humanity and of God. Future studies should thus consider language within its broader social context. Second, this study has compared two languages. As such, further research is necessary to obtain a more comprehensive and in-depth understanding of the matter. Nonetheless, this article provides a steppingstone for future studies into how humans and humanity are conceptualized and positioned through language.

\section{References}

Anderson, B. 1991. Imagined Communities. New York: Verso.

Bayer, 0. 2004. Self-creation? On the dignity of human beings. Modern Theology 20(2): 275-290.

Bennett, B. P. 2018. Sacred Languages of the World: An Introduction. United Kingdom: John Wiley $\&$ Sons.

Bucholtz, M. \& Hall, K. 2007. Language and identity. In. Alessandro Duranti (ed.). A Companion to Linguistic Anthropology, p.p. 369-394. U.K.: Blackwell Publishing Ltd.

Budiono, T. 2016. Verba resiprokal dalam bahasa Arab dan bahasa Indonesia: sebuah studi kontrastif. M.A. Thesis. Universitas Gadjah Mada.

Cailing, R. M. 2018. Fear God and keep His commandments: Foundation for a relationship with God. Review \& Expositor 115(2): 254-263.

Darvin, R. \& Norton, B. 2015. Identity and a model of investment in applied linguistics. Annual Review of Applied Linguistics 35: 36-56.

Egginton, W. 2015. The language of God. In. Egginton, W (ed.). In Defense of Religious Moderation. New York City: Columbia University Press.

Eliade, M. 1959. The Sacred and the Profane: The Nature of Religion. New York: Harcourt Brace \& World.

Ellis, R. 2012. Language teaching research and language pedagogy. United Kingdom: John Wiley \& Sons.

Al-Farisi, Z. 2015. Speech of Iltifat and its Indonesian translation problems. Indonesian Journal of Applied Linguistics 4(2): 78-90.

Gray, K. \& Wegner, D. M. 2010. Blaming God for our pain: Human suffering and the divine mind. Personality and Social Psychology Review 14(1): 7-16. 
Haight, R. 2018. Spirituality, evolution, creator God. Theological Studies 79(2): 251-273.

Hall, G. \& Cook, G. 2012. Own-language use in language teaching and learning. Language Teaching 45(03): 271-308.

Heller, R. L. 2017. Book review: Being human in God's world: An old testament theology of humanity by J. Gordon McConville. Theology Today 74(2): 202-203.

Hidayah, B. 2013. Afiksasi kata kerja masa lampau dalam bahasa Arab dan bahasa Indonesia: Analisis kontrastif. Tafaqquh 1(2): 114-130.

Hidayat, N.S. 2012. Problematika pembelajaran bahasa Arab. Jurnal Pemikiran Islam 37(1): 8288.

Hinkel, E. 2016. Handbook of Research in Second Language Teaching and Learning. United Kingdom: Routledge Taylor \& Francis.

Irving, A. J. D. 2018. The hypostatic union as normative over the relation of God's self-revelation and human cognition in the thought of T.F. Torrance. Irish Theological Quarterly 83(3): 250-268.

Kelly, A. J. 2015. Human consciousness, God and creation. Pacifica: Australasian Theological Studies 28(1): 3-22.

Khokhar, S., Memon, S. \& Siddique, K. 2016. Exploring the role of language in constructing individual identities: A case study of Sindh, Pakistan. International Journal of Humanities and Social Science 6(3): 234-241.

Kuo, J. 2015. Deconstructing bataille: The sacred and the profane. Merici 1: 21-31.

Leaman, O. 2012. Islam. In. Taliaferro, C., Harrison, V. S. \& Goetz, S. (Eds.). The Routledge Companion to Theism. United Kingdom: Taylor \& Francis.

Liepa, D. \& Špona, A. 2015. Teaching and Learning in Higher Education. Society, Integration, Education: Proceedings of the International Scientific Conference 1: 162-172.

Laurin, K., Schumann, K., \& Holmes, J. G. (2014). A Relationship with God? Connecting with the Divine to Assuage Fears of Interpersonal Rejection. Social Psychological and Personality Science 5(7): 777-785.

Lehnert, H. 1997. Reply: Being a Jewish American Germanist after Goldhagen: A response to Herbert Lehnert, "Was wir von Goldhagen lernen können". The German Quarterly 70(2): 174-177.

MacWhinney, B. 2005. Language evolution and human development. In D. Bjorklund \& A. Pellegrini (eds.), Origins of the Social Mind: Evolutionary Psychology and Child Development, pp. 384-410. New York: Guilford Press.

Markhamah, Ngalim, A., Basri, M.M. \& Sabardila, A. 2017. Comparison of personal pronouns between Arabic and its Indonesian translation of Koran. International Journal of Applied Linguistics \& English Literature 6(5): 238-254.

Meadowcroft, T. 2015. Eternity and dust? Cancer and the creative God. Pacifica: Australasian Theological Studies 27(3): 294-314.

Mercier, B., Kramer, S. R. \& Shariff, A. F. 2018. Belief in God: Why people believe, and why they don't. Current Directions in Psychological Science 27(4): 263-268.

Moeller, A. J. \& Catalano, T. 2015. Foreign language teaching and learning. International Encyclopedia of the Social \& Behavioral Sciences, pp. 327-332.

Moore, L. C. 2013. Qur'anic school sermons as a site for sacred and second language socialisation. Journal of Multilingual and Multicultural Development 34(5): 445-458.

Murphy, K. J. 2018. Book review: How human is God? Seven questions about God and humanity in the Bible. Biblical Theology Bulletin: Journal of Bible and Culture, 48(4): 215-216.

Nasution. 2011. Metode Research Penelitian Ilmiah. Jakarta: PT. Bumi Aksara.

Norton, B. 2018. Identity and language learning. In Identity and Language Learning 50(1): 90-112.

Notonogoro. 1987. Pancasila Secara Ilmiah Populer. Jakarta: Bina Aksara.

Nur, T. 2016. Analisis kontrastif dalam studi bahasa. Journal of Arabic Studies 1(2): 64-74. 
Nooraini Othman \& Salasiah Khairollah. 2013. Explorasi hubungan antara personaliti Islamik dan gaya keibubapaan. International Journal of Islamic Thought 4: 38-57.

Alqahtani, M. 2015. The importance of vocabulary in language learning and how to be taught. International Journal of Teaching and Education 3(3): 21-34.

Rennie, B. S. 2007. Mircea Eliade and the perception of the sacred in the profane: Intention, reduction, and cognitive theory. Temenos 43(1): 73-98.

Richards, J. C. \& Schmidt, R. W. 2014. Language and Communication. London: Routledge.

Rickheit, G., \& Strohner, H. 2008. Handbook of communication competence. In. Rickheit, G. \& Strohner, H. (Eds.). Handbook of Communication Competence. Berlin; De Gruyter Mouton

Scheler, Max. 2008. The Constitution of the Human Being. Milwaukee: Marquette University Press.

Tager-Flusberg, H., Paul, R. \& Lord, C. 2013. Language and communication in autism. In. Volkmar, F. R., Paul, R., Klin, A. \& Cohen, D. (Eds.). Handbook of Autism and Pervasive Developmental Disorders. United Kingdom: John Wiley \& Sons.

Tankard, J. W. 1975. The effects of advertising on language: Making the sacred profane. Journal of Popular Culture 9(2): 325-330.

Werhane, P. H. 1996. Community and individuality. New Literary History 27(1): 15-24.

Whitt, J. D. 2016. In the image of God: receiving children with special needs. Review \& Expositor 113(2): 205-216.

Willis, J. R. 2010. Language and identity. In. Arar, H. \& John, H. (Eds.). Asian American X: An Intersection of 21st Century Asian American Voices, pp. 214-221. Michigan: University of Michigan Press.

Wodak, R. 2012. Language, power and identity. Language Teaching 45(02): 215-233.

Wu, E.C. \& Cutright, K. M. 2018. In God's hands: How reminders of God dampen the effectiveness of fear appeals. Journal of Marketing Research 55(1): 119-131.

Young, R. J. C. 2016. That which is casually called a language. PMLA 131(5): 1207-1221.

Zul'azmi Yaakob \& Zailan Moris. 2012. Hak Asasi Manusia (Human Rights) dalam Menangani Krisis Alam Sekitar: Perspektif Seyyed Hossein Nasr. International Journal of Islamic Thought 2: 80-90. 